\title{
Variation in Double-stranded Ribonucleic Acid among Pepper Cultivars
}

\author{
Rodrigo A. Valverde'and James F. Fontenot ${ }^{2}$ \\ Department of Plant Pathology and Crop Physiology, Louisiana Agricultural Experiment Station, \\ Louisiana State University Agricultural Center Baton Rouge, LA 70803
}

\begin{abstract}
Additional index words. cryptic viruses, Capsicum annuum, Capsicum chinense, Capsicum frutescent, electrophoresis
Abstract. Double-stranded ribonucleic acid (dsRNA) was found associated with 51 of 80 healthy pepper (Capsicum annuum L., C. frutescent L., C. chinense Jacq.) cultivars analyzed. In general, dsRNAs were consistent within particular cultivars. Twelve distinct dsRNA profiles that varied in the number and size of the dsRNA segments were obtained. All bell and pimento pepper cultivars analyzed had a similar dsRNA profile. Furthermore, all six cherry pepper cultivars tested were free of dsRNAs. However, an association between the dsRNA profile and the pepper group was not obtained with other cultivars. Selected dsRNAs were transmitted at a high rate through the seed of self-pollinated plants but were not transmitted through grafts to plants that lacked them.
\end{abstract}

DsRNA is not normally found in plants unless they are infected with an RNA virus (Morris and Dodds, 1979). However, there have been several reports of dsRNAs occurring in healthy plants, including pepper (Abou-El Nasr et al., 1985; Grill and Garger, 1981; Valverde et al., 1986; Wakarchuk and Hamilton, 1985). A dsRNA of $\approx 12 \mathrm{~kb}$ from 'California Wonder' pepper has been partially characterized (Valverde et al., 1990).

During a survey for viral diseases of pepper in Louisiana, we noticed that most commercial pepper cultivars contained dsRNAs. These dsRNAs varied in size and number depending on the cultivar analyzed. Furthermore, they appeared to be consistent within specific pepper cultivars. Therefore, the purpose of this investigation was to: a) screen pepper cultivars from various horticultural groups for dsRNAs, b) determine the consistency of the dsRNAs among individual plants from a particular cultivar, and c) explore the possibility of using the dsRNA analysis to identify pepper genotypes.

\section{Materials and Methods}

Cultivars and plant species. Seventy-three cultivars of $\mathrm{C}$. annuum (bell, pimento, ancho, anaheim chili, cayenne, Cuban, jalapeno, serrano, cherry, and yellow wax), seven cultivars of C. frutescens (tabasco), and one line of C. chinense were used in this study. Cultivars and seed sources (Table 1) were grouped according to the horticultural classification of Smith et al. (1987). Leaf tissue from at least 10 individual plants from each cultivar grown in the greenhouse was used for dsRNA extraction.

Extraction and analysis of dsRNA. DsRNA was extracted as described by Valverde et al. (1986) with some modifications. Leaf tissue $(3.5 \mathrm{~g}$ ) was squeezed through a leaf roller in $7.0 \mathrm{ml}$ of $2 \times$ sodium chloride, tris, EDTA $(\mathrm{STE})$ buffer $[1 \times \mathrm{STE}=$ $0.1 \mathrm{M} \mathrm{NaCl}, 0.05 \mathrm{M}$ Tris $\cdot \mathrm{HCl}$ and $0.001 \mathrm{M}$ ethylenediamine tetraacetic acid (EDTA), $\mathrm{pH}$ 6.8.]. The extract was collected in a 50-ml centrifuge tube, and $10 \mathrm{ml}$ of $1 \times$ STE-saturated phenol, $1 \mathrm{ml}$ of $10 \%$ sodium dodecyl sulphate, and $0.5 \mathrm{ml}$ of bentonite

\footnotetext{
Received for-publication 6 Feb. 1990. Approved for publication by the Director of the Louisiana Agricultural Experiment Station as manuscript no. 90-38-4020. We thank B. Villalon, Texas Agricultural Experiment Station, for supplying some of the pepper cultivars used in this study. The cost of publishing this paper was defrayed in part by the payment of page charges. Under postal regulations, this paper therefore must be hereby marked advertisement solely to indicate this fact.

${ }^{1}$ Assistant Professor.

${ }^{2}$ Professor, Dept. of Horticulture.
}

suspension (25 $\mathrm{mg} \cdot \mathrm{ml}^{-1}$, were added. Tubes were shaken for $30 \mathrm{~min}$ and then centrifuged at $8000 \times \mathrm{g}$ for $15 \mathrm{~min}$ in a RC5B Sorvall (DuPont Co., Wilmington, Del.) centrifuge using a SS-34 rotor at 10C. The aqueous phase (upper) was collected, and ethanol was added to a final concentration of $16 \%$. The solution was subjected to two cycles of cellulose (CF-11 Whatman) column chromatography. Columns were made by pouring a suspension of cellulose and $25 \mathrm{ml}$ of $1 \times$ STE with $16 \%$ ethanol (final concentration) into an empty barrel of a $30-\mathrm{ml}$ plastic syringe that had a disk of miracloth paper at the bottom. Samples (aqueous phase) were then added to the column. After washing columns with $100 \mathrm{ml}$ of a solution of $1 \times$ STE and $16 \%$ ethanol, the dsRNA was eluted from the columns with 7 $\mathrm{ml}$ of $1 \times$ STE. DsRNA was precipitated at $-20 \mathrm{C}$ overnight in $50-\mathrm{ml}$ tubes with 2.5 volumes of $95 \%$ ethanol and $0.5 \mathrm{ml}$ of $3 \mathrm{~m}$ sodium acetate, $\mathrm{pH}$ 5.5. Tubes containing dsRNA were centrifuged for $30 \mathrm{~min}$ at $8000 \times \mathrm{g}$. The dsRNA pellets were resuspended in $200 \mu \mathrm{l}$ of electrophoresis buffer $(0.04 \mathrm{M} \mathrm{Tris} \cdot \mathrm{HCl}$, $0.02 \mathrm{M}$ sodium acetate, and $0.001 \mathrm{~m}$ EDTA, $\mathrm{pH} 7.8)$ that contained $20 \%$ glycerol and $0.01 \%$ bromophenol blue. Electrophoresis was performed for $3 \mathrm{~h}$ at $100 \mathrm{~V}$ by use of $6 \%$ polyacrylamide gels $(8 \times 10 \mathrm{~cm} \times 1.5 \mathrm{~mm})$ in a vertical gel apparatus. Gels were stained in ethidium bromide $\left(20 \mathrm{ng} \cdot \mathrm{ml}^{-1}\right)$ for $15 \mathrm{rein}$, visualized with a UV light transillruminator (300 rim), and photographed with Polaroid film, type 57. Size standards used for comparison were dsRNAs extracted from 'California Wonder' pepper $(12 \mathrm{~kb})$ and tobacco plants infected with tobacco necrosis virus $(3.3,1.1$, and $1.0 \mathrm{~kb})$ and tobacco mosaic virus $(6.2,3.0$, 1.4, and $0.6 \mathrm{~kb}$ ) (Valverde et al., 1986).

Seed and graft transmission of dsRNA. To determine the level of seed transmission of selected dsRNAs through three generations of self-pollination, individual plants from five pepper cultivars ('Yolo Wonder', 'Cayenne Long Red', 'Hungarian Wax', 'Jalapeno M-84', and 'Mexican Chili'), each having distinct dsRNA banding patterns, were grown in the greenhouse for three generations. Ten plants from each generation were randomly chosen for dsRNA analysis. The same five cultivars were selected for graft transmission experiments. At least two scions from each of the five cultivars (2-month-old plants) were grafted on rootstock of these cultivars in various combinations. One month after grafting, $3.5 \mathrm{~g}$ of newly developed leaves from each scion were collected and analyzed for dsRNA.

Abbreviation: dsRNA, double-stranded ribonucleic acid. 
Table 1. DsRNA profiles obtained from pepper cultivars. ${ }^{z}$ (Cultivars are grouped according to their horticultural type.)

\begin{tabular}{|c|c|c|}
\hline Group and cultivar & $\begin{array}{l}\text { dsRNA } \\
\text { profile }\end{array}$ & $\begin{array}{c}\text { Seed } \\
\text { source }\end{array}$ \\
\hline \multicolumn{3}{|l|}{ Bell } \\
\hline Agronomico-8 & $\mathrm{b}$ & UCR \\
\hline Delray Bell & b & TAES \\
\hline Domino Hybrid & b & Asgrow \\
\hline Florida VR-2 & $\mathrm{b}$ & LSU \\
\hline Gedeon Hybrid & $\mathrm{b}$ & $\mathrm{UCR}$ \\
\hline Grande Rio 66 & $\mathrm{~b}$ & TAES \\
\hline Jupiter & $\mathrm{b}$ & TAES \\
\hline Keystone Resistant Giant \#3 & $\mathrm{b}$ & Asgrow \\
\hline Olympic Hybrid & $\mathrm{b}$ & Asgrow \\
\hline Marengo & $\mathrm{b}$ & Asgrow \\
\hline Shamrock Hybrid & $\mathrm{b}$ & Asgrow \\
\hline Tambel-2 & $\mathrm{b}$ & TAES \\
\hline Tasty Hybrid & $\mathrm{b}$ & UCR \\
\hline TB-2 & $\mathrm{b}$ & TAES \\
\hline Yolo Wonder & $\mathrm{b}$ & UCR \\
\hline \multicolumn{3}{|l|}{ Pimento } \\
\hline Pimento & $\mathrm{b}$ & UCR \\
\hline Pimento $\mathrm{L}$ & $\mathrm{b}$ & UCR \\
\hline Pimento Perfection & b & TAES \\
\hline Tam F89 & $\mathrm{b}$ & TAES \\
\hline \multicolumn{3}{|l|}{ Ancho } \\
\hline Ancho 101 & $\mathrm{~b}$ & TAES \\
\hline Mexican Chili & a & UCR \\
\hline \multicolumn{3}{|l|}{ Anaheim chili } \\
\hline Anaheim Chili & $\mathrm{g}$ & UCR \\
\hline Anaheim Mild Chili & a & UCR \\
\hline New Mexico 6 & $\mathrm{a}$ & TAES \\
\hline Papri Mild & g & TAES \\
\hline Super Chili & g & LSU \\
\hline Tam Mild Chile-2 & $\grave{h}$ & TAES \\
\hline Tam Mild Chile- 3 & $\mathrm{a}$ & TAES \\
\hline Tam Sweet Chile & $\mathrm{b}$ & TAES \\
\hline \multicolumn{3}{|l|}{ Cayenne } \\
\hline Cajun-1 & $\mathrm{f}$ & LSU \\
\hline Cajun-2 & $\mathrm{a}$ & LSU \\
\hline Cayenne 709 & $\mathrm{~g}$ & LSU \\
\hline Cayenne Large Red Thick & $b, c$ & LSU \\
\hline Cayenne Long Red & $\mathrm{g}$ & UCR \\
\hline Cayenne Long Slim & $\mathrm{c}$ & LSU \\
\hline Durkee & $\mathrm{m}$ & TAES \\
\hline Panola Cayenne & $\mathrm{a}$ & LSU \\
\hline Sport & $\mathrm{m}$ & LSU \\
\hline Super Cayenne & $\mathrm{d}$ & Peto \\
\hline Tam Cayenne & $\mathrm{b}$ & TAES \\
\hline \multicolumn{3}{|l|}{ Cuban } \\
\hline Cubanelle & $\mathrm{b}$ & Peto \\
\hline Pepperoncini & $\mathrm{b}$ & LSU \\
\hline \multicolumn{3}{|l|}{ Jalapeno } \\
\hline Jalapa & $\mathrm{h}$ & Peto \\
\hline Jalapeño & $\mathrm{a}$ & LSU \\
\hline Jalapeño $M-84$ & $\mathrm{f}$ & UCR \\
\hline Jalapeño M-88 & $\mathrm{f}, \mathrm{h}, \mathrm{j}$ & Peto \\
\hline Jalapeño M-89 & $\mathrm{h}$ & TAES \\
\hline Jalapeto & g,h & Peto \\
\hline Jumbo Jalapéño & 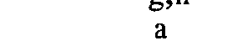 & Peto \\
\hline Tam Mild Jalapeño & a & TAES \\
\hline Tam Sweet Jalapeño & a & TAES \\
\hline Tam Veracruz Jalapeño & a & TAES \\
\hline Tam Yellow Jalapeño & a & TAES \\
\hline \multicolumn{3}{|l|}{ Serrano } \\
\hline Serrano Chili & $\mathrm{i}, \mathrm{k}$ & Peto \\
\hline Tam Hidalgo & $\mathrm{i}$ & TAES \\
\hline Tampiqueño & a & TAES \\
\hline
\end{tabular}

Table 1. Continued.

\begin{tabular}{|c|c|c|}
\hline Group and cultivar & $\begin{array}{l}\text { dsRNA } \\
\text { profile }\end{array}$ & $\begin{array}{c}\text { Seed } \\
\text { source }\end{array}$ \\
\hline \multicolumn{3}{|l|}{ Cherry } \\
\hline Cherry & a & LSU \\
\hline Large Cherry & $\mathbf{a}$ & UCR \\
\hline Sweet Cherry & $\mathbf{a}$ & UCR \\
\hline Tam Hot & a & TAES \\
\hline Tam Sweet & a & TAES \\
\hline Tiger & a & LSU \\
\hline \multicolumn{3}{|l|}{ Yellow wax } \\
\hline Gold Spike & g & LSU \\
\hline Habanero & $i$ & LSU \\
\hline Habanero Orange & $\mathrm{a}$ & TAES \\
\hline Habanero Red & g & TAES \\
\hline Hungarian.Wax & $\mathrm{c}$ & UCR \\
\hline Hungarian Yellow Wax & a & TAES \\
\hline Sante Fe Grande & c & TAES \\
\hline Sweet Banana & $\mathbf{a}$ & UCR \\
\hline Tam Cascabella & $\mathbf{a}$ & TAES \\
\hline Tam Rio Grande & a & TAES \\
\hline Tam Gold Spike & a & TAES \\
\hline \multicolumn{3}{|l|}{ Tabasco } \\
\hline Dat'l & a & TAES \\
\hline Greenleaf Tabasco & e & LSU \\
\hline Greenleaf Tabasco & $\mathbf{a}$ & TAES \\
\hline LSU Tabasco & e & LSU \\
\hline McLlhenny Select & $\mathbf{a}$ & $\mathrm{MC}$ \\
\hline McLlhenny Tabasco & a & TAES \\
\hline Tam Tabasco & $\mathrm{b}$ & TAES \\
\hline
\end{tabular}

${ }^{2}$ DsRNA profile designation was assigned according to the number and relative mobility of dsRNAs after polyacrylamide gel electrophoresis. Typical profiles are shown in Fig. 1.

yUCR = Univ. of California, Riverside; LSU = Louisiana State Univ.; Peto $=$ Petoseed, Inc; TAES = Texas Agricultural Experiment Station; Asgrow $=$ Asgrow Seed $\mathrm{MC}=$ McLlhenny $\mathrm{Co}$.

\section{Results and Discussion}

Twelve distinct dsRNA banding patterns (profiles) were obtained after electrophoretic analysis of C. annuum and C. frutescens (Fig. 1). DsRNA was not detected in C. chinense. An arbitrary designation (a through $\mathrm{m}$ ) was given to each dsRNA profile according to the number and relative mobility (size) of the dsRNAs detected by gel electrophoresis (Table 1).

Most of the dsRNAs found in pepper are similar to the genomic dsRNAs of cryptic viruses (Boccardo et al., 1987). Cryptic viruses are spherical, multisegmented dsRNA (1-3 kb) plant viruses that do not induce symptoms in their hosts, are transmitted at a high rate through seed, and are not transmitted mechanically or by grafting. Some dsRNAs found here could be the genomes of cryptic viruses. They were transmitted at a high rate through seed of self-pollinated plants and have sizes similar to the dsRNAs of cryptic viruses. It is unlikely that these dsRNAs constitute the genome of conventional plant viruses. Attempts to transmit several dsRNA types by grafting, which is a standard method for transmission of plant viruses and virus-like agents, failed. Furthermore, pepper plants that had these dsRNAs did not show visible virus symptoms. Regardless of the origin, these dsRNAs are consistently associated with some specific pepper cultivars and, therefore, may have great utility.

Smith et al. (1987) have grouped peppers grown in the United States according to fruit morphology, size, color, and usage. DsRNA profile $b$ was associated with all 15 bell pepper cultivars examined. Furthermore, previous analysis of 10 other bell pepper cultivars yielded a similar dsRNA profile (Valverde et al., 


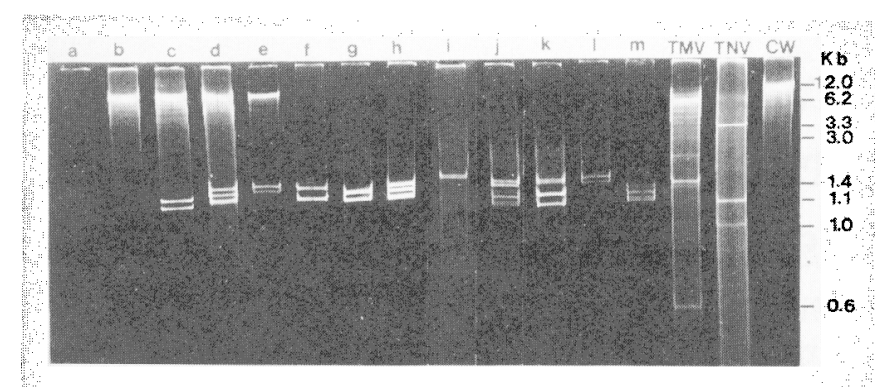

Fig. 1. Polyacrylamide gel electrophoresis $(6 \%)$ profiles of dsRNA extracted from individual plants of 12 pepper cultivars. To each dsRNA profile, an arbitrary designation was given. Channels are labeled according to the dsRNA profile. Lane a, 'Jumbo Jalapeño'; lane b, 'Pimento L'; lane c, 'Cayenne Large Red Thick'; lane d, 'Super Cayenne'; lane e, 'Greenleaf Tabasco'; lane f, 'Jalapeño M84'; lane g, 'Gold Spike'; lane h, 'Jalapa'; lane i, 'Serrano Chili'; lane j, 'Jalapeño M-88'; lane k, 'Serrano Chili'; lane l, 'Habanero'; and lane $\mathrm{m}$, 'Sport'. Size standards are dsRNAs extracted from tobacco plants infected with tobacco mosaic virus (TMV) and tobacco necrosis virus (TNV) and 'California Wonder' pepper (CW). Molecular size is given in kilobases $(\mathrm{kb})$. Electrophoresis was conducted at $100 \mathrm{~V}$ for $3 \mathrm{~h}$. Migration of dsRNAs is from top to bottom [cathode $(-)$ to anode $(+)$ ].

1990). 'Cubanelle' and 'Pepperoncini', which belong to the $\mathrm{Cu}$ ban group, and all four pimento cultivars also had this dsRNA profile. This commonality may indicate common ancestry. All six cultivars of the cherry group lacked dsRNAs. DsRNA profiles from cultivars of other groups were variable. Therefore, except for the above groups, dsRNA profiles did not coincide with the present horticultural classification.

Most pepper cultivars with dsRNAs yielded profiles that were consistent in all 10 plants examined; the exceptions were 'Serrano Chili', 'Cayenne Large Red Thick', 'Jalapeto', and 'Jalapeño M-88'. In these cases, individual plants within a cultivar had different dsRNA profiles (Table 1). Furthermore, 'Jalapeño M' plants from two seed lots had distinct dsRNA types. Plants from the 1984 seed lot had dsRNA type f, those from a 1989 seed lot had dsRNA type $h$, but those from the 1988 seed lot had either type f, h, or j (Table 1). Similarly, 'Greenleaf Tabasco' from two sources yielded different dsRNA profiles. These variations could indicate an actual mixture of seed from more than one cultivar, a partial infection of the seed lot by a cryptic virus, cross pollination, or segregation of the different dsRNAs encoded in parental genomes. The latter could be related to lack of homozygosity in these cultivars.
Preliminary studies on the inheritance of these dsRNAs indicate that they are transmitted through the seed, both maternally and paternally. Some dsRNA profiles shown in Fig. 1 (c, $\mathrm{d}, \mathrm{e}, \mathrm{h}$, and j) appear to be mixtures of two profiles. Since many cultivars are derived from crosses, these mixtures were not surprising.

'Jalapeño M' plants of two seed lots were phenotypically indistinguishable. Therefore, dsRNA profiles could be used to differentiate seed lots. The genetic background of pepper cultivars may also be traced by looking at their dsRNA profiles. This could be done not only by electrophoretic analysis but also by molecular hybridization using a cloned cDNA probe specific for a selected dsRNA segment.

The development of a computer database of the dsRNA profiles of all commercial pepper cultivars could be useful not only for plant breeders, but also for commercial seed companies. Analysis of dsRNA can be complimentary to other techniques, such as enzyme analysis for studying the taxonomy and evo-: lution of peppers (McLeod et al., 1983).

\section{Literature Cited}

Abou-El Nasr, M. A., A.T. Jones, and M.A. Mayo. 1985. Detection of double-stranded RNA in particles of Vicia cryptic virus and in Vicia faba tissues and protoplasm. J Gen. Virol. 66:2453-2460.

Boccardo, G., V. Lisa, E. Louisoni, and R.G. Milne. 1987. Cryptic plant viruses. Adv. Virus Res. 32:171-214.

Grill, L.K. and S.J. Garger. 1981. Identification and characterization of double-stranded RNA associated with cytoplasmic male sterility in Vicia faba. Proc. Natl. Acad. Sci. USA 78:7043-7046.

McLeod, M.J., S.I. Guttman, W.H. Eshbaugh, and R.E. Rayle. 1983. An electrophoretic study of evolution in Capsicum (Solanaceae). Evolution 37:562-574.

Morris, T.J. and J.A. Dodds. 1979. Isolation and analysis of doublestranded RNA from virus infected plant and fungal tissue. Phytopathology 69:854-858.

Smith, P. G., B. Villalon, and P.L. Villa. 1987. Horticultural classification of peppers grown in the United States. HortScience 22:1113.

Valverde, R.A., J.A. Dodds, and J.A. Heick. 1986. Double-stranded ribonucleic acid from plants infected with viruses having elongated particles and undivided genomes. Phytopathology 76:459465.

Valverde, R. A., S. Nameth, O. Abdallha, O. Al-Muss, P. Desjardins, and A. Dodds. Indigenous double-stranded RNA from pepper (Capsicum annuum). Plant Sci. 67:195-201.

Wakarchuk, D.A. and R.I. Hamilton. 1985. Cellular double-stranded RNA in Phaseolus vulgaris cultivar Black turtle soup. Plant Mol. Biol. 5:55-64. 